\title{
Keanekaragaman Serangga Polinator Pada Tanaman Nanas (Ananas comosus (L.) Merr.) Di Desa Bincau
}

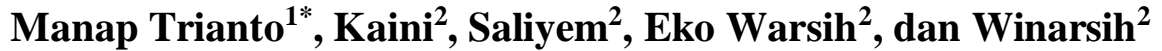 \\ ${ }^{1}$ Laboratorium Entomologi, Departemen Biologi Tropika, Fakultas Biologi, Universitas \\ Gadjah Mada, Yogyakarta, Indonesia \\ ${ }^{2}$ GCI Science and Technology, Kabupaten Banjar, Kalimantan Selatan, Indonesia \\ *E-mail: manaptrianto@mail.ugm.ac.id
}

\begin{abstract}
Abstrak: Serangga polinator adalah hewan yang memindahkan serbuk sari dari antera bunga jantan ke bagian stigma bunga betina. Tujuan dari penelitian ini adalah untuk mengetahui keanekaragaman serangga penyerbuk di perkebunan nanas (Ananas comosus (L.) Merr.) Desa Bincau, Kecamatan Martapura, Kabupaten Banjar, Kalimantan Selatan. Pengambilan sampel dilakukan secara purposive sampling dengan menggunakan perangkap lem kuning (Yellow sticky trap). Pengamatan serangga dilakukan secara visual control. Pengamatan dimulai pukul 07.00-18.00 WITA yang dibagi menjadi 3 periode waktu, yaitu: 07.00-10.00 WITA, 11.00-14.00 WITA dan 15.00-18.00 WITA. Data yang diperoleh dianalisis menggunakan indeks keanekaragaman Shannon-Wiener $\left(\mathrm{H}^{\prime}\right)$. Hasil penelitian menunjukkan bahwa total individu serangga penyerbuk di perkebunan nanas adalah 517 individu, yang terdiri dari 4 ordo dan 8 famili. Famili serangga tertinggi didominasi oleh Formicidae, sedangkan terendah adalah famili Syrpidae. Nilai keanekaragaman serangga polinator yaitu $\mathrm{H}^{\prime}=$ 1,760 yang menunjukkan bahwa tingkat keanekaragaman serangga polinator pada perkebunan Nanas (Ananas comosus (L.) Merr.) Di Desa Bincau, Kecamatan Martapura, Kabupaten Banjar, Kalimantan Selatan dalam kategori sedang.
\end{abstract}

\section{Kata Kunci: Keanekaragaman, Serangga Polinator, Tanaman Nanas, Desa Bincau}

Abstract: Pollinator insects is an animal that moves pollen from the male anther of a flower to the female stigma of a flower. The purpose of this study was to determine the diversity of insects pollinators in the pineapple (Ananas comosus (L.) Merr.) plantation of Bincau Village, Martapura District, Banjar Regency, South Kalimantan. Sampling was done by purposive sampling using a yellow sticky trap. The customer observations are made in visual control. Observation starts at 07.00-18.00 WITA which is divided into 3 time periods, namely: 07.00-10.00 WITA, 11.00-14.00 WITA and 15.00-18.00 WITA. The data obtained were analyzed using the diversity index Shannon-Wiener $\left(\mathrm{H}^{\prime}\right)$. The results showed that the total individual of pollinator insects in pineapple plantations was 517 individuals, consisting of 4 order and 8 family. The highest abundance of 
insects is dominated by the Formicidae Family, while the lowest abundance is the Syrpidae Family. Value insect pollinator diversity found among the sites that $\mathrm{H}^{\prime}=1.760$ which indicates that the level of diversity of insect pollinators on plantations Pineapple (Ananas comosus (L.) Merr.) in the Bincau Village, Martapura District, Banjar Region, South Kalimantan in the medium category.

\section{Keywords: Diversity, Pollinator Insects, Pineapple, Bincau District}

Tanaman nanas (Ananas comosus (L.) Merr.) merupakan salah satu jenis tanaman yang tidak bisa melakukan penyerbukan sendiri atau autogami (Andini, 2014; Wati, 2019). Penyerbukan sendiri atau autogami adalah suatu proses menempelnya serbuk sari dari suatu bunga pada kepala putik atau dengan kata lain bahwa penyerbukan ini terjadi jika serbuk sari dan putik berasal dari satu bunga itu sendiri (Miftahorrachman, 2010; Rizki, 2020). Bunga pada tanaman nanas bergantung pada serangga sebagai polinator. Dengan kata lain bahwa kualitas buah nanas sangat ditentukan dari jumlah kunjungan dan penyerbukan yang dilakukan oleh serangga polinator (Kevan dan Phillips, 2001; Suprianto et al., 2020). Lebih dari $80 \%$ spesies tanaman bergantung pada serangga dalam proses penyerbukan atau membawa serbuksari dari bunga satu ke bunga lain (Faheem, et $a l ., 2004)$. Serangga polinator pada umumnya mengunjungi suatu tanaman karena adanya faktor penarik seperti bentuk, warna, serbuk sari, dan nektar bunga sebagai penarik primer serta aroma sebagai penarik sekunder (Raju dan Ezradanam, 2002). Selain itu, hal tersebut juga dapat terjadi karena dipengaruhi oleh faktor lingkungan seperti suhu, kelembaban, intensitas cahaya, serta kecepatan angin di lingkungan tersebut (Faheem, et al., 2004; Trianto dan Purwanto, 2020).

Kehadiran berbagai jenis serangga pada suatu tanaman dapat membantu dalam proses penyerbukan silang (Apituley et al., 2012; Trianto et al., 2020). Beberapa keuntungan yang dapat ditimbulkan dari penyerbukan silang yaitu dapat meninkatkan hasil buah, biji (Kearns dan Inouye, 1997) dan dapat meningkatkan variabilitas keturunan pada tanaman itu sendiri (Barth, 1991). Peran serangga sebagai polinator tanaman telah banyak dilaporkan, khususnya di Indonesia. Misalnya, peran serangga polinator di lahan kebun buah agribisnis (Suwondo et al., 2016), keanekaragaman serangga polinator pada kebun kakao (Amirullah et al., 2016), serangga polinator pada tumbuhan edelweiss (Hidayat et al., 2016) dan lain sebagainya.

Peran serangga polinator dalam proses penyerbukan suatu tanaman saat ini masih terabaikan. Bahkan perencanaan konsep pertanian modern saat ini lebih cenderung pada proses penambahan nutrisi tambahan tanaman dan proses pengendalian hama untuk tujuan menghasilkan produk yang maksimal (Eka, 2006). Penggunaan pestisida dalam pengelolaan pertanian dapat berdampak negatif pada serangga kanopi pada tanaman itu sendiri. penurunan jumlah kelimpahan serangga terutama serangga penyerbuk (polinator) 
dapat mengurangi kualitas dan produksi tanaman (Kevan dan Phillips, 2001). Hal ini dapat terjadi karena penggunaan pestisida tersebut juga berdapampak pada serangga non target (kelimpahan dan diversitas serangga menurun).

Desa Bincau merupakan salah satu daerah yang berada di Kecamatan Martapura, Kabupaten Banjar, Kalimantan Selatan. Di desa ini terdapat beberapa lahan kebun nanas yang dikembangbiakan. Berdasarkan hasil wawancara kepada masyarakat yang melakukan budidaya tanaman nanas, bahwa beberapa tahun terakhir terjadi penurunan produksi nanas. Produktivitas nanas ditentukan oleh berbagai faktor, diantaranya adalah faktor pollinator atau hewan penyebuk. Serangga pollinator dapat membantu proses penyerbukan (polinasi) yang membantu produksi hasil panen pertanian (Borror et al, 1992). Pada bidang pertanian, penyerbukan tanaman oleh serangga merupakan salah satu kunci keberhasilan produksi pertanian (Kevan \& Phillips, 2001). Berdasarkan uraian di atas diperlukan kajian tentang keanekaragaman serangga polinator di perkebunan nanas (Ananas comosus (L.) Merr.) di Desa Bincau, Kecamatan Martapura, Kabupaten Banjar.

\section{METODE PENELITIAN}

Penelitian ini dilaksanakan pada bulan April-Mei 2020 di perkebunan tanaman nanas (Ananas comosus (L.) Merr.) di Desa Bincau, Kecamatan Martapura, Kabupaten Banjar, Kalimantan Selatan. Metode yang digunakan dalam penelitian ini adalah survey pada lahan perkebunan nanas seluas $2000 \mathrm{~m}^{2}$ dengan sampling secara purposive sampling pada luas lahan $200 \mathrm{~m}^{2}$. Lokasi penelitian yang digunakan adalah lahan pertanian yang ditanami tanaman nanas secara bersamaan.

Pengambilan sampel serangga polinator dilakukan dengan membuat perangkap lem kuning (Yellow sticky trap). Perangkap serangga terbuat dari botol plastik yang di bagian dalamnya dilapisi kertas minyak berwarna kuning dan bagian luar dari botol diolesi dengan lem serangga. Perangkap diberi penyangga yang terbuat dari kayu dengan panjang kurang lebih $60 \mathrm{~cm}$ yang pada bagian ujungnya telah diruncingkan. Perangkap lem kuning (Yellow sticky trap) yang digunakan dalam penelitian ini berjumlah 15 buah yang ditancapkan pada areal perkebunan nanas secara purposive sampling. Perangkap ditancapkan $30 \mathrm{~cm}$ dari permukaan tanah (ketinggian perangkap disesuaikan dengan tinggi tanaman). Pengamatan serangga polinator dimulai pada pukul 07.00-18.00 WITA yang dibagi menjadi 3 periode waktu pengamatan yaitu: pada pukul 07.00-10.00 WITA, 11.00-14.00 WITA, dan 15.00-18.00 WIT. Serangga polinator yang terjebak dengan perangkap lem kuning diambil dengan menggunakan sarung tangan plastik untuk selanjutnya dilakukan proses identifikasi. Metode yang digunakan dalam pengamatan serangga adalah dengan menghitung jumlah spesies dan individu serangga polinator. Serangga yang diperoleh diawetkan menggunakan alkohol $70 \%$ untuk proses identifikasi dengan menggunakan buku identifikasi serangga (Borror, 1996). Indeks keragaman 
serangga polinator dihitung menggunakan indeks keragaman Shannnon-Wiener ( $\left.\mathrm{H}^{\prime}\right)$ (Magurran, 2004).

\section{HASIL DAN PEMBAHASAN}

Total serangga polinator yang dikoleksi pada tanaman nanas adalah sebesar 517 individu yang terdiri atas 8 famili dari 4 ordo yaitu Diptera, Homoptera, Hymenoptera, dan Lepidoptera. Ordo Diptera terdiri dari 3 famili yaitu Drosophilidae, Muschidae, dan Syrpidae. Ordo Homoptera terdiri dari 1 famili yaitu Cicadellidae. Ordo Hymenoptera terdiri dari 3 famili yaitu Apidae, Formicidae, dan Vespidae. Sedangkan Ordo Lepidoptera terdiri dari 1 famili yaitu Papilionidae (Tabel 1).

Tabel 1. Jumlah Individu Serangga Polinator Pada Perkebunan Nanas

\begin{tabular}{|c|c|c|c|c|c|c|}
\hline \multirow{2}{*}{ No. } & \multirow{2}{*}{ Ordo } & \multirow{2}{*}{ Famili } & \multicolumn{3}{|c|}{ Waktu Penelitian (WITA) } & \multirow{2}{*}{ Tota } \\
\hline & & & 07.00-10.00 & $11.00-14.00$ & $15.00-18.00$ & \\
\hline \multirow[t]{3}{*}{1} & Diptera & Drosophilidae & 38 & 5 & 27 & 70 \\
\hline & & Muschidae & 19 & 11 & 17 & 47 \\
\hline & & Syrpidae & 8 & 2 & 4 & 14 \\
\hline 2 & Homoptera & Cicadellidae & 11 & 4 & 7 & 22 \\
\hline \multirow[t]{3}{*}{3} & Hymenoptera & Apidae & 47 & 0 & 39 & 86 \\
\hline & & Formicidae & 92 & 45 & 67 & 204 \\
\hline & & Vespidae & 26 & 5 & 14 & 45 \\
\hline 4 & Lepidoptera & Papilionidae & 14 & 6 & 9 & 29 \\
\hline \multicolumn{3}{|c|}{ Total } & 255 & 78 & 184 & 517 \\
\hline
\end{tabular}

Berdasarkan data pada Tabel 1, dapat diketahui bahwa jumlah individu serangga polinator tertinggi terjadi pada pukul 07.00-10.00 WITA dengan total 255 individu, yang didominasi oleh famili Formicidae dengan jumlah 92 individu. Sedangkan jumlah individu serangga polinator terendah terjadi pada pukul 11.00-14.00 WITA dengan total 78 individu, yang juga didominasi oleh famili Formicidae. Pada pukul 11-14.00 WITA tidak ditemukan sama sekali famili Apidae pada lokasi penilitian. Hal ini dapat terjadi karena dipengaruhi oleh beberapa faktor, misalnya seperti suhu dan volume nektar pada bunga tanaman. Menurut Jumar (2000), serangga memiliki kisaran suhu tertentu dimana serangga dapat hidup, serangga akan mati jika melewati kisaran toleransi tersebut. Pada umumnya kisaran suhu yang efektif adalah suhu minimum $15^{\circ} \mathrm{C}$, suhu optimum $25^{\circ} \mathrm{C}$, dan suhu maksimum $45^{\circ} \mathrm{C}$. Lebih lanjut Handani et al., (2014) menjelaskan bahwa suhu sangat berpengaruh pada proses fisiologi serangga, karena serangga merupakan organisme yang bersifat poikiloterm, sehingga suhu tubuh serangga banyak dipengaruhi oleh suhu lingkungan. Suhu akan mempengaruhi aktivitas`serangga, penyebaran, pertumbuhan dan perkembangbiakan serangga. Sedangkan menurut Syamsudin (2013) volume nektar pada bunga juga memegang peran penting dalam mempengaruhi keanekaragaman serangga polinator di alam. Volume nektar pada bunga tinggi pada pagi

BIOLOGI SEL (VOL 9 NO 2 EDISI JUL-DES 2020 ISSN 2252-858X/E-ISSN 2541-1225) PAGE 157 
hari dan akan terus menurun hingga malam hari. Hal inilah yang akan berpengaruh terhadap kunjungan serangga pada suatu tanaman.

Jumlah individu serangga polinator terendah terjadi pada pukul 11.00-14.00 WITA. Hal tersebut dapat terjadi, karena disebabkan aktifitas serangga polinator yang sebagian besar dilakukan pada pagi (07.00-10.00 WITA) dan sore (15.00-18.00 WITA) hari. Selain itu juga, adapun faktor yang mempengaruhi hal tersebut yaitu suhu lingkungan. Pada pukul 11.00-14.00 WITA terjadi peningkatan suhu yang melewati batas suhu optimum serangga yaitu menjadi $33^{\circ} \mathrm{C}$. Hal ini sesuai dengan pernyataan Choli (2006) bahwa serangga penyerbuk umumnya berkunjung pada pagi hari yang bertepatan dengan bunga mekar atau suhu sekitar $26^{\circ} \mathrm{C}$. Selanjutnya, Frank (2012) menjelaskan bahwa pada siang hari, jumlah serangga polinator pada suatu tanaman akan mengalami penurunan dibanding saat pagi hari. Berdasarkan data pada Tabel 1 juga dapat diketahui bahwa pada pukul 15.00-18.00 WITA, jumlah individu serangga polinator terjadi penaikan. Hal ini dapat terjadi karena suhu pada pukul 15.00-18.00 WITA masih dalam rentan suhu yang dapat ditoleransi oleh serangga polinator untuk melakukan aktifitas yaitu $28^{\circ} \mathrm{C}$. Hal ini didukung oleh penjelasan Jumar (2000) bahwa keadaan suhu yang dapat ditoleransi oleh serangga untuk melangsungkan kehidupannya yaitu sekitar 15$45^{\circ} \mathrm{C}$. Komposisi masing-masing famili serangga polinator yang didapatkan pada penelitian ini disajikan pada Gambar 1.

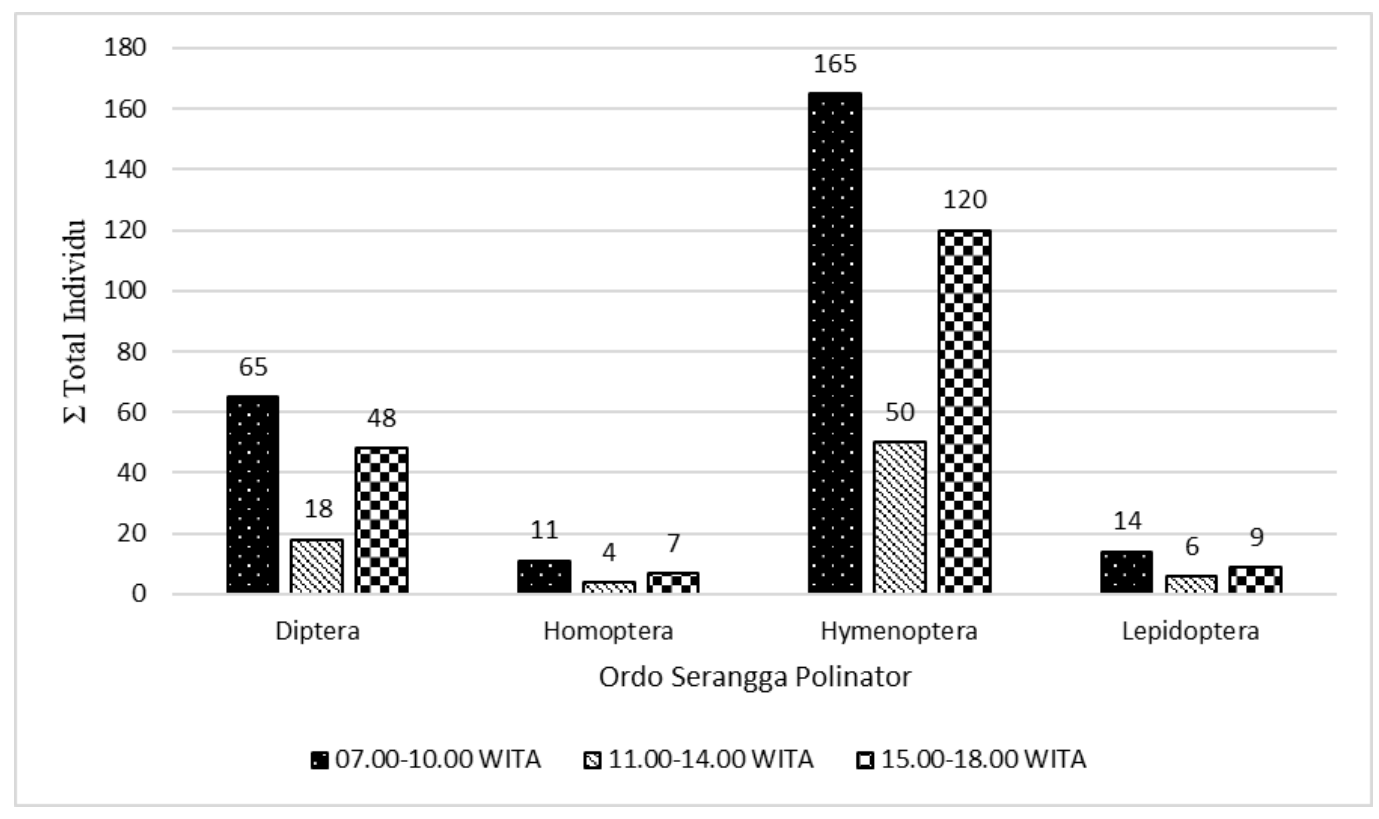

Gambar 1. Komposisi Famili Serangga Polinator

Berdasarkan gambar grafik di atas, ordo Hymenoptera menunjukkan jumlah individu tertinggi yaitu 335 individu dengan rincian famili yaitu Formicidae (165 individu), Apidae (120 individu), dan Vespidae (50 individu). Serangga polinator famili Formicidae melakukan aktivitas (keluar dari sarang) biasanya pada waktu pagi dan sore 
hari saat suhu lingkungan tidak terlalu panas. Untuk memperoleh cahaya matahari yang cukup dalam proses menjalankan aktivitasnya, famili ini akan menuju ke bagian pucuk tanaman (Setyawan, 2007). Menurut Riyanto (2007) secara ekologi, serangga polinator famili formicidae dapat bermanfaat bagi jenis hewan lainnya dan tumbuhan, karena dalam suatu rantai makanan masing-masing organisme memiliki peran atau manfaatnya masingmasing.

Interaksi antara serangga polinator dan tanaman berbunga merupakan suatu hubungan yang saling menguntungkan antar organisme. Dalam interaksi tersebut serangga memperoleh makanan, sedangkan tanaman mendapat bantuan dalam proses penyerbukan tanaman. Bagi tanaman, asosiasi dengan serangga berdampak positif, terutama dengan terjadinya proses penyerbukan silang. Bagi serangga, asosiasi dengan tumbuhan memberi keuntungan, yaitu sebagai sumber pakan berupa serbuksari (pollen) dan nektar (Amalia, 2013).

Pada Tabel 1 dan Gambar 1 juga dapat dilihat bahwa terdapat beberapa famili serangga polinator dengan jumlah yang rendah atau bahkan tidak ada sama sekali. Misalnya famili Apidae sama sekali tidak ditemukan pada lokasi peneltian pada pukul 11.00-14.00 WITA. Hal ini sesuai dengan pernyataan Amalia (2013) bahwa pada siang hari famili ini akan beristirahat di tempat atau lokasi yang terlindung dari pancaran sinar matahari yaitu di pohon atau tanaman yang teduh. Periode aktivitas famili tersebut akan terjadi kembali pada sore hari dan pada malam hari di puncak pohon atau pada naungan untuk beristirahat dan berlindung. Kelimpahan serangga polinator yang hadir pada tanaman berbunga seperti pada tanaman nanas menunjukkan ketertarikan serangga tersebut pada bunga nanas. Seperti pernyataan Frank (2012) bahwa kepadatan bunga dan keragaman bunga merupakan faktor yang paling penting dan menentukan keragaman serangga penyerbuk pada tanaman berbunga dan menghasilkan stabilitas kepadatan populasi serangga penyerbuk (Ghazoul, 2006; Trianto et al., 2020). Tanaman berbunga akan menghasilkan dan meningkatkan keragaman serangga penyerbuk. Dalam prosesnya serangga penyerbuk pada dasarnya membutuhkan dua komponen utama yaitu tempat untuk bersarang dan ketersediaan sumber pakan bagi serangga tersebut. Oleh karena itu keragaman serangga polinator ditentukan oleh ketersediaan sumber pakan pada suatu tanaman yaitu nektar dan tepungsari tanaman (Amirullah, 2018).

Keanekaragaman atau diversitas merupakan penggabungan antara jumlah jenis dan jumlah individu masing-masing jenis dalam satu komunitas (Noughton dan Wolf, 1992). Permasalahan mengenai keanekaragaman umumnya mengarah pada keanekaragaman jenis. Oleh karena itu, pengukuran keanekaragaman dapat dilakukan dengan melihat jumlah jenis tertentu dan kelimpahan relatif jenis tersebut dalam satu komunitas. Keanekaragaman atau diversitas ditentukan oleh dua komponen yaitu jumlah spesies organisme dalam suatu komunitas dan jumlah individu antara spesies sama atau 
seimbang (Desmukh, 1992; Trianto dan Marisa, 2020). Hasil analisis keanekaragaman indeks Shanon-Wiener dalam penelitian ini disajikan pada Tabel 2.

Tabel 2. Indeks Keanekaragaman Serangga Polinator pada Perkebunan Nanas

\begin{tabular}{|c|c|c|c|c|c|}
\hline No & Famili & Jumlah Individu & $\mathbf{P i}$ & $\ln \mathbf{p i}$ & $-\Sigma$ pi In pi \\
\hline 1 & Drosophilidae & 70 & 0,135397 & $-1,999$ & 0,271 \\
\hline 2 & Muschidae & 47 & 0,090909 & $-2,398$ & 0,218 \\
\hline 3 & Syrpidae & 14 & 0,027079 & $-3,609$ & 0,098 \\
\hline 4 & Cicadellidae & 22 & 0,042553 & $-3,157$ & 0,134 \\
\hline 5 & Apidae & 86 & 0,166344 & $-1,794$ & 0,298 \\
\hline 6 & Formicidae & 204 & 0,394584 & $-0,929$ & 0,366 \\
\hline 7 & Vespidae & 45 & 0,087041 & $-2,441$ & 0,212 \\
\hline \multirow[t]{2}{*}{8} & Papilionidae & 29 & 0,056093 & $-2,880$ & 0,161 \\
\hline & Total & 517 & & & 1,760 \\
\hline
\end{tabular}

Berdasarkan perhitungan indeks keanekaragaman Shannon-Wienner (Tabel 2) serangga polinator pada perkebunan nanas yang terdapat di Desa Bincau menunjukkan tingkat keanekaragaman sedang yaitu $H^{\prime}=1,760$. Hal ini sesuai dengan pernyataan Maguran (2004) bahwa tingkat keanekargaman suatu organisme dikategorikan sedang apabila $1<\mathrm{H}^{\prime}<3$. Keanekaragaman serangga polinator yang didapatkan dapat terjadi kemungkinan karena dipengaruhi oleh beberapa faktor misalnya jumlah dan warna bunga pada tanaman nanas. Menurut Syamsudin (2013) bahwa jumlah dan warna bunga pada suatu jenis tanaman merupakan faktor penentu kehadiran serangga polinator. Keanekaragaman serangga polinator berkaitan dengan melimpahnya sumberdaya tanaman, terutama serbuk sari dan nektar yang terdapat pada tanaman itu sendiri. Laksono (2007) menyatakan keanekaragaman spesies dapat digunakan untuk menilai keadaan suatu komunitas, apabila jumlah jenis suatu organisme banyak maka keanekaragamannya juga besar pada suatu wilayah.

\section{KESIMPULAN}

Hasil penelitian menunjukkan bahwa terdapat 517 individu serangga polinator pada tanaman nanas yang terdiri atas 8 famili dari 4 ordo yaitu Diptera, Homoptera, Hymenoptera, dan Lepidoptera. Jumlah individu serangga polinator tertinggi terdapat pada pukul 07.00-10.00 WITA dan terendah pada pukul 11.00-14.00 WITA. Kategori tingkat keanekaragaman serangga polinator pada tanaman nanas (Ananas comosus (L.) Merr.) di Desa Bincau, Kecamatan Martapura, Kabupaten Banjar adalah sedang $\left(\mathrm{H}^{\prime}=\right.$ $1,760)$.

\section{DAFTAR PUSTAKA}

Amalia, S. (2013). Кири-Kuрu di Kampus Universitas Padjadjaran Unpad Jatinangor. Bandung: Universitas Padjajaran. 
Amirullah, Wirdhana, S., \& Afdaliana, D. (2018). Keanekaragaman Serangga Polinator di Perkebunan Kakao (Theobroma cacao L.) Desa Puudongi Kecamatan Kolono Kabupaten Konawe Selatan Sulawesi Tenggara. Biowallacea. 5: 735-749.

Andini, P. (2014). Sirup Gula Buah (Nanas dan Rambutan) yang Diproses Secara Hidrolisis Asam dan Pemanasan. Skripsi. Palembang: Politeknik Negeri Semarang. Apituley, F. L., Leksono, A. S., \& Yanuwiadi, B. (2012). Kajian Komposisi Serangga Polinator Tanaman Apel (Malus sylvestris Mill) di Desa Poncokusumo Kabupaten Malang. Kajian Komposisi Serangga: 85-96.

Barth, F. G. (1991). Insect and Flowers-The Biology and Partnership. New Jersey: Princeton University Press.

Borror, D. J., Triplehorn, C. A., \& Johnson, N. F. (1996). Pengenalan Pelajaran Serangga Ed ke6. Yogyakarta: Gajah Mada Universiry Press.

Choli, D. (2006). Pemberdayaan Serangga Penyerbuk dan Tanaman Pemikat untuk Meningkatkan Produktifitas Jarak Pagar (Jatrohpa curcas L). Balitas. Doc. Malang: BPTTS.

Desmukh, I. (1992). Ekologi dan Biologi Tropika. Jakarta: Yayasan Obor Indonesia.

Eka, P. R. (2006). Polinasi: Servis Alam yang Terabaikan. http://www.google.com. Diakses tanggal 10 Juni 2020.

Faheem, M., Aslam, M., \& Razaq, M. (2004). Pollination ecology with special reference to insect - A Review. J Res Sci. 15(4): 395-409

Frank, A. (2012). Kajian Komposisi Serangga Polinator Tanaman Apel (malus sylvestris Mill) di Desa Poncokusumo. Malang: PPSB.

Ghazoul, J. (2006). Floral diversity and the facilitation of pollination. J Ecol. 94: 295304.

Handani, M., Natalina, M., \& Febrita, E. (2014). Inventory of Insect Pollinators in Long Beans (Vygna cylindrica) Agricultural Land Pekanbaru City and Development to Learning Resources on The Concept of Interaction Patterns of Living Creatures in Junior High School. Riau: Universitas Riau.

Hidayat, P.A., Pratiknyo, H., \& Basuki, E. (2016). Keragaman Serangga Polinator Pada Tumbuhan Edelweiss Jawa (Anaphalis javanica) di Gunung Slamet Jawa Tengah. Seminar Nasional Pendidikan dan Saintek. 25: 481-491.

Jumar. (2000). Entomologi Pertanian. Jakarta: PT Rineka Cipta.

Kearns, C. A., \& Inouye, D. W. (1997). Pollinator, Flowering Plants and Consevation Biology. Bio Sci. 47: 297-307.

Kevan, P. G., \& Phillips, T. P. (2001). The Economic Impact of Polinator Declines: An Approach to Assesing the Consequences. Conservation Ecology. 5(1): 8.

Laksono, S. (2007). Ekologi Pendekatan Deskriptif dan Kuantitatif. Malang: Bayu Media.

Magguran, A. (2004). Measuring biological diversity. Malden: Blackwell Publishing.

BIOLOGI SEL (VOL 9 NO 2 EDISI JUL-DES 2020 ISSN 2252-858X/E-ISSN 2541-1225) PAGE 161 
Miftahorrachman. (2010). Sistem Penyerbukan Kelapa Genjah Salak (Cocos nucirefa L.). Buletin Palma. 39: 111-118.

Naughton, S. J., \& Wolf, L. L. (1992). Ekologi Umum, Edisi Kedua. Yogyakarta: UGM Press.

Raju, A. J. S., \& Ezradanam, V. (2002). Pollination ecology and fruiting behavior in a monoecious species, Jatropha curcas L. (Euphorbiaceae). Cur. Science. 83: 13951398.

Riyanto. (2007). Kepadatan, Pola Distribusi dan Peranan Semut pada Tanaman di Sekitar ingkungan Tempat Tinggal. Jurnal Penelitian Sains. 5: 10-25.

Rizki, M. (2020). Penyerbukan Sendiri Geitonogami Gambir (Uncaria gambir) Tipe Udang. Skripsi. Padang: Universitas Andalas.

Setiawan, Y. (2007). Kolonisasi Formicidae Hitam (Dolichoderus thoracicus Smith) padaTanaman Kakao (Theobroma cacao L) dengan Pemberian Pakan Alternatif. Surakarta: Jurusan Biologi. FMIPA. UNS.

Suprianto, Trianto, M., Alam, N., \& Kirana, N. G. A. G. C. (2020). Karakter Morfologi dan Analisis Daerah Conserved Gen Elongation Factor 1a (EF1a) Pada Lepidotrigona terminata. Jurnal Metamorfosa. 7: 30-39.

Suwondo, Febriata, E., \& Khairi, K. (2016). Struktur Komunitas Serangga Polinator di Kebun Buah Agribisnis Fakultas Pertanian Riau. Jurnal Biogenesis. 13: 45-50.

Syamsuardi. (2013). Jenis-Jenis Serangga Pengunjung Bunga Neriumoleander Linn. (Apocynaceae) di Kecamatan Pauh, Padang. Padang: Universitas Andalas.

Trianto, M., \& Marisa, F. (2020). Diversity of Bees and Wasp (Hymenoptera) in Cowpea (Vigna sinensis L.) in Agricultural Area at Martapura District, Banjar Regenc, South Kalimantan. Journal of Science and Technology. 9: 29-33.

Trianto, M., \& Purwanto, H. (2020). Morphological Characteristics and Morphometrics of Stingless Bees (Hymenoptera: Meliponini) in Yogyakarta, Indonesia. Biodiversitas. 21: 2619-2628.

Trianto, M., Marisa, F., \& Siswandari, N. P. (2020). Kelimpahan Nisbi, Frekuensi dan Dominansi Jenis Lalat di Beberapa Pasar Tradisional di Kecamatan Martapura. Jurnal Metamorfosa. 7: 21-29.

Trianto, M., Marisa, F., Sukmawati, \& Nuraini. (2020). Keanekaragaman Jenis Rayap Pada Perkebunan Kelapa Sawit dan Perkebunan Karet di Kabupaten Banjar Kalimantan Selatan. Jurnal Biologi Makassar. 5: 199-209.

Wati, P. R. (2019). Analisis Faktor-Faktor Geografi dan Pola Persebaran Budidaya Nanas Madu di Kabupaten Pemalang Sebagai Induksi Geografis. Skripsi. Semarang: Fakultas Ilmu Sosial, Universitas Negeri Semarang.

Wratten, S. D., \& Emden, V. H. (1994). Habitat Manajement for Enchanched Activity of Natural Enemies of Insect Pests - Ecology and Integreted Farming System. Chilchester: Willey. 